\title{
Influence in the reproductive planning and the women's satisfaction with the discovery of being pregnant in the quality of prenatal care in Brazil
}

José Marcos de Jesus Santos 1

https://orcid.org/0000-0001-5122-1469

Thais Santos de Matos 2

iD https://orcid.org/0000-0001-6016-7062

Rosemar Barbosa Mendes 3

D https://orcid.org/0000-0002-4860-7413

Carla Kalline Alves Cartaxo Freitas 4

iD https://orcid.org/0000-0001-7604-9132

Adriana Moraes Leite 5

https://orcid.org/0000-0001-8327-8718

lellen Dantas Campos Verdes Rodrigues 6

https://orcid.org/0000-0002-5593-4172

1 Departamento de Enfermagem Materno-Infantil e Saúde Pública. Escola de Enfermagem de Ribeirão Preto. Universidade de São Paulo. Ribeirão Preto, SP, Brasil. CEP: 14040-902. E-mail: jsmarcos@usp.br

2-4,6 Departamento de Enfermagem. Universidade Federal de Sergipe. Lagarto, SE, Brasil.

5 Departamento de Enfermagem Materno-Infantil e Saúde Pública. Escola de Enfermagem de Ribeirão Preto. Universidade de São Paulo. Ribeirão Preto, SP, Brasil.

\begin{abstract}
Objectives: to analyze the influence on reproductive planning and the women's satisfaction with the discovery of being pregnant in prenatal care characteristics.

Methods: a cross-sectional and quantitative study was carried out between March and July 2018 at a low-risk maternity hospital in the Brazilian Northeast region. A total of 652 puerperal women were evaluated in an interview and by their prenatal care card. The Chisquare test and the Odds Ratio were used for statistical analysis.

Results: the pregnancy planning was reported by $42 \%(n=274)$, and the women's satisfaction of being pregnant was $64.1 \%(n=418)$ of the interviewees. Reproductive planning was associated with early initiation of prenatal care $(O R=2.48, C I 95 \%=1.61-3.82)$ and the women received information about the referral maternity for childbirth (OR=1.44, C195\%=1.05-1.99). The women's satisfaction with their pregnancy was also associated with early initiation of prenatal care $(O R=2.18$; $C 195 \%=1.47-3.25)$. It should be noted that the performance of six or more prenatal care consultations was less frequent among pregnant women who had not planned their pregnancy $(O R=0.43, C 195 \%=0.27-0.66)$ and they felt unsatisfied with the discovery of being pregnant $(O R=0.56$; CI95\%=0.37-0.84).

Conclusions: Pregnancy planning and women's satisfaction with the discovery of being pregnant favors the performance of prenatal care with better indicators.

Key words Family planning, Sexual and reproductive health, Prenatal care, Contraception
\end{abstract}

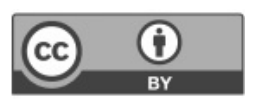




\section{Introduction}

In Brazil, family planning was defined in Article 2 of the Brazilian Law number 9.263/1996 as a set of measures on fertility regulation that aims to ensure equal rights in the Constitution for women, men or couples to establish, limit or increase of offspring. It consists of preventive and educational activities with an approach to the means, methods and techniques that are available by the Ministry of Health on the regulation of fertility in the country. ${ }^{1}$

The term reproductive planning was adopted in the Brazilian ministerial publications as a substitution for family planning in order to be more comprehensive in relation to sexual and reproductive rights. Health professionals' actions in reproductive planning should involve, mainly, guidance/counseling and educational and clinical activities that contribute to a healthier sexual practice, with the possibility of spacing births and to have an adequate recovery of the female body after childbirth, and to improve their conditions to care for their children and also to perform other duties. ${ }^{2}$

In this context, it is worthy to mention that in 1996 and 2006, the proportion of unplanned births in Brazil was $50 \%$ and $46 \%$, respectively. ${ }^{3}$ In 2014, a nationwide study showed that more than half of the pregnancies in the country still occur in an unplanned manner, including reports on maternal unsatisfied with the discovery of being pregnant and the attempts of abortion. ${ }^{4}$ This reinforces the necessity to improve counseling and advice on contraception by health professionals. 5

It is known that there is still a considerable gap between what is advocated in the sexual and reproductive healthcare actions and what women at a reproductive age experience in the public health services in the country. ${ }^{6}$ The limited supply of contraceptive methods, the inadequate physical space at the health services for guidance, and the lack of professional training on contraception ${ }^{7}$ are also cited.

This situation is not restricted in developing countries $^{8}$ and a considerable proportion of international health units do not have or do not follow any reproductive planning protocols. ${ }^{9}$ In the U.S., an estimate of $51 \%$ of the 6 million births per year occur of unplanned pregnancy. ${ }^{8}$ More than half of all pregnancies are also unplanned in 28 states and the District of Columbia. The highest rates of unplanned pregnancies were observed in Delaware (62\%) and Hawaii $(61 \%) .10$ In this context, the American College of Obstetricians and Gynecologists strongly recommends women to have early access on repro- ductive planning and encourages obstetricians, gynecologists, and other health professionals to use any assistance as opportunities to talk and counsel about contraception. ${ }^{8}$

It is also worth mentioning the importance of prenatal care consults be seen by health professionals as strategic moments to encourage women in regard to prevent the recurrence of an unplanned or unwanted pregnancy and to control their fertility. ${ }^{11}$ This is due to the fact that the quality of prenatal care must offer to the users activities on promotion and prevention, besides diagnosis and treatment. 12

Thus, this study justified to test the alternative hypothesis that an unplanned pregnancy and/or the women's were unsatisfied when they discovered they were pregnant, it may negatively influence the quality of prenatal care. This hypothesis, if confirmed, would represent risks of severe implications to the mother-child binomial. Therefore, this study aimed to analyze the influence of reproductive planning and the women's satisfaction with the discovery of being pregnant in the prenatal care characteristics.

\section{Methods}

This is a cross-sectional and quantitative study, with descriptive and analytical approaches, conducted between March and July 2018. A total of 655 puerperal women were evaluated by an interview and by the prenatal card during the immediate postpartum period.

The study was carried out at Zacarias Júnior Maternity, located in the municipality of Lagarto, the State of Sergipe in Brazil. The institution has 4 private obstetric beds, 6 pre-delivery beds and 31 rooming beds. The maternity attends childbirths with public and/or private financing from normal-risk pregnant women from Lagarto and other surrounding cities.

The eligible population for the study consisted of 1,250 women based on the annual estimate of births provided by the management department of the institution where the research was conducted. The Barbetta 13 formula was used to calculate the sample. A confidence level of $97 \%$ and a sample error of $3 \%$ were considered to obtain a satisfactorily representative sample. A $10 \%$ safety margin in the calculated number was used, resulting in 655 pregnant women were interviewed.

The regnant women were selected by a simple random sampling from a list of daily hospitalization, and all the women who had delivered live fetuses at any gestational weight or gestational age and still- 
births with birth weight $\geq 500 \mathrm{~g}$ or $\mathrm{GA} \geq 20$ weeks, and whose birth took place at Zacarias Júnior Maternity. Women who did not speak or did not understand Portuguese or who had severe mental disorders were excluded. It is noteworthy that there were only two participants with stillbirths with birth weight $\geq 500$ g or $\mathrm{GA} \geq 20$ weeks, who both agreed to answer the questions from this present study.

Face-to-face interviews were performed with the pregnant women at intervals of at least 6 hours after childbirth and the participants' prenatal cards were checked to collect data. The questionnaire of this research contained sociodemographic and other variables related to reproductive planning and prenatal care.

The presentation of the detailed results refers to the following questions: Has the current pregnancy been planned? How did you feel when you discovered you were pregnant? What was your perception in relation to timing when you knew you were pregnant? The following variables were used to analyze the influence of reproductive planning and maternal satisfaction with the discovery of being pregnant in the prenatal care characteristics: early onset, number of consultations, follow-up by the same professional, and guidance on the referred maternity for childbirth versus planned pregnancy and the pregnant woman's satisfaction when she discovered she was pregnant. We point out that some of the criteria on Programa de Humanização no Pré-natal e Nascimento (PHPN)14 (Prenatal and Birth Humanization Program) and the Rede Cegonha (Stork Network) 15 were used to consider the quality of prenatal care in this present study.

In the statistical analysis, three participants were excluded because of the number of unanswered items on reproductive planning and prenatal care, which resulted in 652 women evaluated. Univariate and bivariate techniques were used to obtain the distribution of absolute and relative frequency values. Associations were investigated by using the chi-square test for categorical variables. The Odds Ratio (OR) was estimated as a measure of association and its respective 95\% confidence intervals (CI95\%) using the Mantel-Haenszel method. A significance of $5 \%$ was adopted in all cases. The package used was the IBM ${ }^{\circledR}$ SPSS - Statistical Package for the Social Sciences 20.0 Mac (SPSS 20.0 Mac, SPSS Inc., Chicago, Illinois, USA).

This study is linked to the Projeto Nascer em Lagarto, SE: Inquérito Municipal sobre Parto e Nascimento (Born in Lagarto, SEProject: Municipal Survey on Childbirth and Birth), approved in March 2018 by the Research Ethics Committee at the
Universidade Federal de Sergipe, under th document number: 2.553.774 and CAAE number: 82426418.0.0000.5546. The researchers followed the guidelines and regulatory standards recommended in Resolution Number: 466/12 of the Conselho Nacional de Saúde (National Health Council) on human researches. The pregnant women signed the Informed Consent Form with a guarantee of refusal at any time without any harm.

\section{Results}

The mean age of participants was $25.9 \pm 6.8$ years. There was an almost equal distribution among the housing areas, with $49.4 \%(n=322)$ in the urban area and $49.2 \% \quad(n=321)$ in the rural area. The ethnicity/skin color mixed, was the most mentioned $(70.2 \% ; n=458)$ and $53.2 \%(n=347)$ graduated from high school or had a higher education level. More than half did not have a paying job $(72.3 \%, n=471)$ and lived with the partner at the time of the research $(85.6 \%, \mathrm{n}=558)$.

The planned pregnancy was reported by $42 \%$ $(n=274)$ of the interviewees and $64.1 \%(n=418)$ were satisfied to discover they were currently pregnant. As for the time in which this finding occurred, $43.7 \%(n=285)$ of the women answered that they really wanted to get pregnant now and $32.8 \%$ $(n=214)$ wanted to get pregnant a little later (Table $1)$.

The analysis on the interference of the reproductive planning in the prenatal care characteristics showed that planned pregnancy is associated with the early onset of the follow-up $(\mathrm{OR}=2.48$, $\mathrm{CI} 95 \%=1.61-3.82)$ and receiving guidance on the referred maternity for childbirth during this process $(\mathrm{OR}=1.44$, CI95\%=1.05-1.99). Six or more consultations were also infrequent among women who did not plan for the current pregnancy $(\mathrm{OR}=0.43$; CI95\% $=0.27-0.66)(p<0.05)$ (Table 2).

Similarly, the women's satisfaction with the discovery of being pregnant was associated with the early onset of prenatal care follow-up $(\mathrm{OR}=2.18$; $\mathrm{CI} 95 \%=1.47-3.25)$. Six or more consultations were infrequent among women who were unsatisfied with the discovery of being pregnant $(\mathrm{OR}=0.56$, CI95\% $=0.37-0.84)(p<0.05)$ (Table 3$)$.

Figure 1 shows the result of the proportional distribution of statistically significant associations between reproductive planning and maternal satisfaction when discovering pregnancy with the prenatal care characteristics. One can observe that, albeit without significant proportional differences, planned pregnancy and women's satisfaction on 
Table 1

Descriptive results on pregnant women's responses on reproductive planning-related issues ( $n=652)$. Lagarto, Sergipe, Brazil, 2018.

Reproductive planning-related issues

N $\%$

1. Has the current pregnancy been planned?

$\begin{array}{lcc}\text { Yes } & 274 & 42 \\ \text { No } & 376 & 57.7 \\ \text { Did not answer } & 2 & 0.3\end{array}$

2. How did you feel when you discovered you were pregnant?

Satisfied

$418 \quad 64.1$

More or less satisfied

164

Unsatisfied

61

Did not answer

3. What was your perception of the timing when you knew you were pregnant?

$\begin{array}{lcc}\text { I really wanted to get pregnant now. } & 285 & 43.7 \\ \text { I wanted to get pregnant a little later } & 214 & 32.8 \\ \text { I did not want to get pregnant } & 149 & 22.9 \\ \text { Did not answer } & 4 & 0.6\end{array}$

Table 2

Associations between prenatal characteristics and reproductive planning ( $n=652)$. Lagarto, Sergipe, Brazil, $2018 .$.

\begin{tabular}{|c|c|c|c|c|c|c|}
\hline \multirow{3}{*}{$\begin{array}{l}\text { Variables related to the } \\
\text { quality in prenatal care }\end{array}$} & \multicolumn{4}{|c|}{ Reproductive planning } & \multirow[t]{3}{*}{ OR (Cl95\%) } & \multirow[t]{3}{*}{$p\left(\chi^{2}\right)$} \\
\hline & \multicolumn{2}{|c|}{ Yes $(n=274)$} & \multicolumn{2}{|c|}{ No $(n=376)$} & & \\
\hline & $\mathrm{n}$ & $\%$ & $\mathrm{n}$ & $\%$ & & \\
\hline \multicolumn{7}{|l|}{ Early onset } \\
\hline Yes & 237 & 86.5 & 275 & 73.1 & $2.48(1.61-3.82)$ & $<0.001$ \\
\hline No & 33 & 13.5 & 95 & 26.9 & & \\
\hline \multicolumn{7}{|l|}{ Number of consultations } \\
\hline 6 or more & 239 & 87.2 & 283 & 75.3 & $0.43(0.27-0.66)$ & $<0.001$ \\
\hline$\leq 5$ & 32 & 12.8 & 88 & 24.7 & & \\
\hline \multicolumn{7}{|c|}{ Follow-up by the same professional } \\
\hline Yes & 175 & 64.3 & 235 & 63.0 & $1.05(0.76-1.46)$ & 0.728 \\
\hline No & 97 & 35.7 & 138 & 37.0 & & \\
\hline \multirow{2}{*}{\multicolumn{7}{|c|}{$\begin{array}{l}\text { Guidance on the referred maternity } \\
\text { for childbirth }\end{array}$}} \\
\hline & & & & & & \\
\hline Yes & 164 & 61.4 & 189 & 52.4 & $1.44(1.05-1.99)$ & 0.024 \\
\hline No & 103 & 38.6 & 172 & 47.6 & & \\
\hline
\end{tabular}

OR= odds ratio, $\mathrm{Cl} 95 \%=95 \%$ Confidence Interval, $p\left(\chi^{2}\right)=$ Chi-square test $p$-value.

Participants who did not respond adequately to the questions were excluded from the analysis. 
discovering the pregnancy, it favors the prenatal care with better indicators.

Table 3

Associations between prenatal characteristics and maternal satisfaction with the discovery of being pregnant $(n=652)$. Lagarto, Sergipe, Brazil, 2018.

\begin{tabular}{|c|c|c|c|c|c|c|}
\hline \multirow{3}{*}{$\begin{array}{l}\text { Variables related to the } \\
\text { quality in prenatal care }\end{array}$} & \multicolumn{4}{|c|}{ Maternal satisfaction with the discovery of being pregnant } & \multirow[t]{3}{*}{ OR (Cl95\%) } & \multirow[t]{3}{*}{$p\left(\chi^{2}\right)$} \\
\hline & \multicolumn{2}{|c|}{ Yes $(n=418)$} & \multicolumn{2}{|c|}{ *No $(n=225)$} & & \\
\hline & $\mathrm{n}$ & $\%$ & $\mathrm{n}$ & $\%$ & & \\
\hline \multicolumn{7}{|l|}{ Early onset } \\
\hline Yes & 348 & 83.3 & 159 & 70.7 & $2.18(1.47-3.25)$ & $<0.001$ \\
\hline No & 63 & 16.7 & 63 & 29.3 & & \\
\hline \multicolumn{7}{|l|}{ Number of consultations } \\
\hline 6 or more & 350 & 83.7 & 168 & 74.7 & $0.56(0.37-0.84)$ & 0.005 \\
\hline$\leq 5$ & 63 & 16.3 & 54 & 25.3 & & \\
\hline \multicolumn{7}{|c|}{ Follow-up by the same professional } \\
\hline Yes & 258 & 62.3 & 149 & 66.5 & $0.83(0.59-1.17)$ & 0.292 \\
\hline No & 156 & 37.7 & 75 & 33.5 & & \\
\hline \multirow{2}{*}{\multicolumn{7}{|c|}{$\begin{array}{l}\text { Guidance on the referred maternity } \\
\text { for childbirth }\end{array}$}} \\
\hline & & & & & & \\
\hline Yes & 233 & 57.5 & 115 & 53.2 & $1.19(0.85-1.65)$ & 0.305 \\
\hline No & 172 & 42.5 & 101 & 46.8 & & \\
\hline
\end{tabular}

OR= odds ratio, $\mathrm{Cl} 95 \%=95 \%$ Confidence Interval, $p\left(\chi^{2}\right)=$ Chi-square test $p$-value

*The responses "more or less satisfied" and "unsatisfied" were included.

Participants who did not respond adequately to the questions were excluded from the analysis.

Figure 1

Proportional distribution between planned pregnancy $(n=274)$ / unplanned pregnancy $(n=376)$ and maternal satisfaction with the discovery of being pregnant $(n=418)$ / unsatisfied $(n=225)$ with prenatal care characteristics. Lagarto, Sergipe, Brazil, 2018.

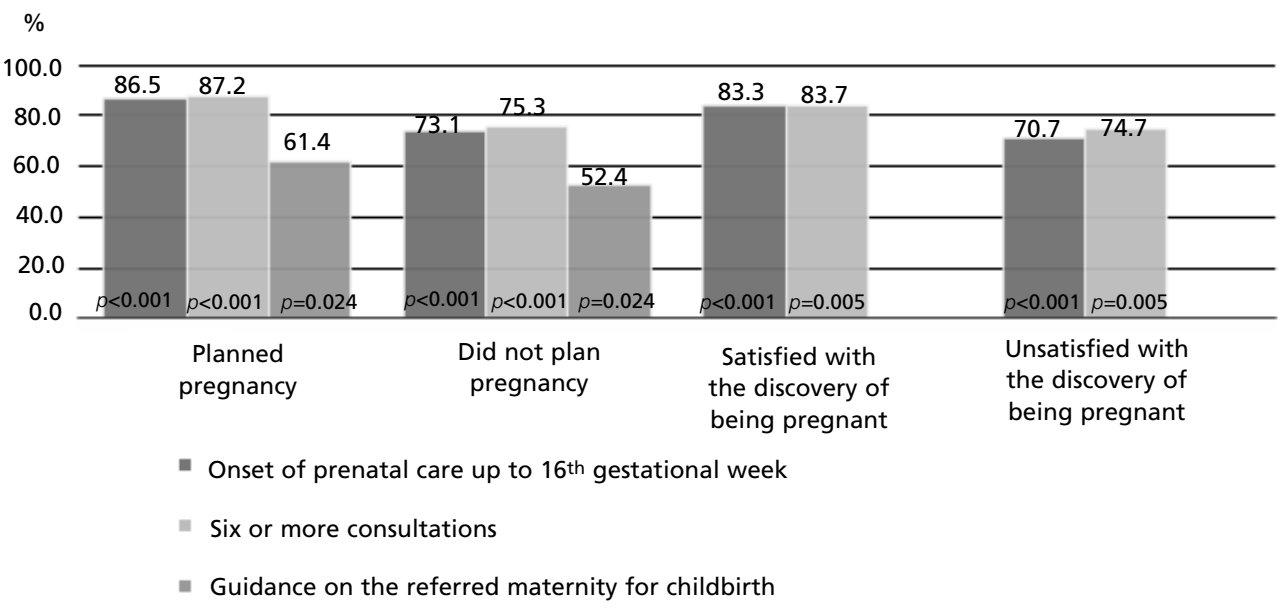

These results obtained statistical significance in the association of analysis $(p<0.05)$ using the chi-square test. 


\section{Discussion}

This present study evidenced that planned pregnancy and women's satisfaction with the discovery of being pregnant favor prenatal care with better indicators (early onset of follow-up, higher number of consultations and receiving guidance on the referred maternity for childbirth). These findings are still scarce in the national scientific community and are limited in the international literature since few international studies that test statistical associations between reproductive planning and the quality of prenatal care little have been found. ${ }^{16-18}$

More than half of the pregnant women that were interviewed said they had not planned to get pregnant. This result is in agreement with other national studies6,19-21 and international studies, ${ }^{8,10}$ which also identified an unplanned pregnancy prevalence higher than $50 \%$. It is known that the lack or deficiency of this reproductive planning favors the onset of depressive symptoms after childbirth 20 and, if such gestation occurs in adolescence, there is usually a postponement or impairment of the educational projects, lower probability of professional qualification and absolute financial dependence on the family. 22

In this context, it should be emphasized that health professionals should act by promoting health education individually or in groups, discussing what is reproductive planning, its importance in the women, men or couples' life, the contraceptive methods provided by the Ministry of Health, how to use them and their possible side effects or complications, always considering the users' personal desire for contraception. 23

Regarding to the women's satisfaction with the discovery of being pregnant, only slightly more than half were satisfied with this news. It is believed that this result is influenced by the high number of unplanned pregnancies in this present study, as well as the time in which this discovery occurred, since a third of the interviewees wanted this event to occur in a further time. It is noted that among adolescents and young adults, reproductive planning care is even of a greater importance because of the risk behaviors and negative consequences of unsafe sexual practices in these phases of life. 24

It is understood that mothers' feelings in relation to pregnancy and their baby can be influenced by the characteristics of prenatal care they received, and health professionals should pay more attention to the quality and the minimum procedures that should be offered to women during this period. However, in order to ensure a good management in care in the field of contraception, these professionals must have updated technical, scientific and cultural knowledge directed to sexual and reproductive health in which the population needs in their area of coverage/performance. ${ }^{26}$

It is also worth noting that the limitations of this study are related to the reliability of the data that were obtained exclusively through the report of pregnant mothers who were interviewed, and are related to reproductive planning, women's satisfaction with the discovery of their pregnancy and prenatal care characteristics.

Thus, it is emphasized that this present study confirmed the alternative hypothesis that an unplanned pregnancy and/or women are unsatisfied with the discovery of their pregnancy, are negatively influenced in the quality of prenatal care, which could result in a late onset of gestational follow-ups, with a smaller number of consultations and without receiving any guidance on the referred maternity for childbirth during this process.

Therefore, it is believed that this study may contribute to the discussion of public health policies aimed at sensitizing health professionals and the population about the importance of reproductive planning in maternal and child outcomes in Brazil.

\section{Authors' contribution}

The study design and planning: JMJS, TSM, RBM, IDCVR. Data collection, analysis, and interpretation: JMJS, TSM, RBM. Elaboration or review of the manuscript: JMJS, TSM, RBM, CKACF, AML, IDCVR. Approval of the final version of the manuscript: JMJS, TSM, RBM, CKACF, AML, IDCVR. Public responsibility for the content: JMJS, TSM, RBM, IDCVR. 


\section{References}

1. Brasil. Lei no 9.263, de 12 de janeiro de 1996. Regula o $\S 7^{\circ}$ do art. 226 da Constituição Federal, que trata do planejamento familiar, estabelece penalidades e dá outras providências. Brasília, DF: Diário Oficial da União; 1996.

2. Brasil. Saúde Sexual e Saúde Reprodutiva. Brasília, DF: Ministério da Saúde; 2010

3. Lago TDG. Nascimentos não planejados no Brasil eram $46 \%$ em 2006. Diminuíram?. R bras Est Pop. 2015;32(2):387-94.

4. Viellas EF, Augusto M, Dias B, Viana J, Bastos MH Assistência pré-natal no Brasil. Cad Saúde Pública. 2014;30:85-100

5. Brasil. Pré-natal e Puerpério: atenção qualificada e humanizada - manual técnico. Brasília, DF: Ministério da Saúde; 2006.

6. Borges ALV, Cavalhieri FB, Hoga LAK, Fujimori E, Barbosa LR. Planejamento da gravidez: prevalência e aspectos associados. Esc Enferm USP. 2011; 45(spe2) 1679-84.

7. Santos RB, Barreto RM, Bezerra ACL, Vasconcelos MIO. Processo de readequação de um planejamento familiar: construção de autonomia feminina em uma unidade básica de saúde no Ceará. RECIIS. 2016; 10 (3): 1-10.

8. American College of Obstetricians and Gynecologists. Reproductive life planning to reduce unintended pregnancy. Committee Opinion No. 654. Obstet Gynecol. 2016; 127 (654): e66-9.

9. Robbins CL, Gavin L, Carter MW, Moskosky SB. The link between reproductive life plan assessment and provision of preconception care at publicly funded health centers. Perspect Sex Reprod Health. 2017; 49 (3): 167-72.

10. Kost K. Unintended Pregnancy Rates at the State Level: Estimates for 2010 and Trends Since 2002. New York: Guttmacher Institute; 2015.

11. Maeda TC, Parreira BDM, Silva SR, Oliveira ACD. Importância atribuída por puérperas às atividades desenvolvidas no pré-natal. Rev Enferm Atenção Saúde. 2014; 3 (2): 6-18.

12. Brasil. Atenção ao pré-natal de baixo risco. Brasília, DF: Ministério da Saúde; 2012

13. Barbetta PA. Estatística aplicada às ciências sociais. Santa Catarina: UFSC; 2014

14. Brasil. Portaria no 569/MS de 1 o de Junho de 2000. Institui o Programa de Humanização no Pré-natal e Nascimento, no âmbito do Sistema Único de Saúde. Brasília, DF: Diário Oficial da União; 2000.
15. Brasil. Portaria no $1.459,24$ de junho de 2011. Institui, no âmbito do Sistema Único de Saúde, a Rede Cegonha. Brasília, DF: Diário Oficial da União; 2011.

16. Gipson JD, Koenig MA, Hindin MJ. The effects of unintended pregnancy on infant, child, and parental health: A review of the literature. Studies in Family Planning. 2008;39.

17. Mosher WD, Jones J, Abma JC. Intended and unintended births in the United States: 1982-2010. Natl Health Stat Report. 2012; (55): 1-28.

18. Kost K, Landry DJ, Darroch JE. Predicting Maternal Behaviors During Pregnancy: Does Intention Status Matter? Fam Plann Perspect. 1998; 30 (2): 79.

19. Prietsch SOM, González-Chica DA, Cesar JA, MendozaSassi RA. Gravidez não planejada no extremo Sul do Brasil: prevalência e fatores associados. Cad Saúde Pública. 2011; 27 (10): 1906-16.

20. Brito CNO, Alves SV, Ludermir AB, Araújo TVB. Depressão pós-parto entre mulheres com gravidez não pretendida. Rev Saúde Pública. 2015; 49: 33.

21. Coelho EDAC, Andrade MLDS, Vitoriano LVT, Souza JDJ, Silva DO, Gusmão MEN, et al. Associação entre gravidez não planejada e o contexto socioeconômico de mulheres em área da Estratégia Saúde da Família. Acta Paul Enferm. 2012; 25 (3): 415-22.

22. Taborda JA, Silva FC, Ulbricht L, Neves EB. Consequências da gravidez na adolescência para as meninas considerando-se as diferenças socioeconômicas entre elas. Cad Saúde Coletiva. 2014; 22 (1): 16-24.

23. Rocha ACF, Holanda SM, Lima ACS, Aquino PS. Atividades de enfermagem no planejamento familiar: projeto de extensão universitária. Rev Extensão em Ação. 2016; 1 (13): 69-82.

24. Moura LNB, Gomes KRO. Planejamento familiar: uso dos serviços de saúde por jovens com experiência de gravidez. Ciên Saúde Coletiva. 2014; 19 (3): 853-63.

25. Piccinini CA, Carvalho FT, Ourique LR, Lopes RS Percepções e sentimentos de gestantes sobre o pré-natal. Psic Teor Pesq. 2012; 28 (1): 27-33.

26. Dombrowski JG, Pontes JA, Assis WALM. Atuação do enfermeiro na prescrição de contraceptivos hormonais na rede de atenção primária em saúde. Rev Bras Enferm. 2013; 66 (6): 827-32.

Received on May 5, 2018

Final version presented on December 10, 2018

Approved on May 30, 2019 